\title{
CHALLENGES FACED BY THE REGIONAL FINANCIAL INSTITUTIONS ENGAGED IN ENTERPRISE FINANCING
}

\author{
PRZEMYSŁAW PLUSKOTA \\ University of Szczecin, Faculty of Management and Economics of Services, POLAND \\ e-mail: przemyslaw.pluskota@wzieu.pl
}

\author{
RECEIVED \\ ACCEPTED \\ 10 December 2018 \\ 28 December 2018 \\ JEL \\ CLASSIFICATION \\ G21, G23, H70, L26
}

KEYWORDS

financial instruments, loans funds, guarantee funds, regional development funds, micro, small and medium enterprises

ABSTRACT

\begin{abstract}
Micro-, small- and medium-sized enterprises encounter many barriers to their activity, one of the major ones being the limited access to capital and its sources. A significant role in overcoming the obstacles connected with inadequate access to capital is played by the special funds established by the state as well as regional and local authorities. Poland can boast a relatively well developed system of institutions whose fundamental purpose is financing of business activity. These first and foremost include banks and various kinds of funds, such as loan funds and loan guarantee funds. The regional market and the financial system creates numerous processes. In the theory of economics there are many concepts and views regarding the impact of the financial system on economic growth. Most of them indicate that development of the financial system stimulates economic growth. The mission of regional development should involve any and all local (regional) financial institutions, including those that are not banks, such as loan funds and loan guarantee funds. Another element of the regional financial markets are regional development funds (RDF) that may become the local managers and stimulators of regional development, in its broad sense and in a long-time perspective.
\end{abstract}

\section{Introduction}

Regional financial market players, particularly the micro-, small- and medium-sized enterprises, encounter many barriers in running their business activity. Apart from any administrative obstacles and those connected with know-how, the most frequent problems are related to the limited access to capital. This issue is to be mitigated by the institutional infrastructure which in a broad sense includes public authorities, colleges and universities, 
institutions and organisations aimed at supporting development of enterprises (among others, regional development agencies, business incubators, knowledge transfer centres, technological parks) as well as financial institutions on both national and regional level.

Enterprises from the SME sector may use the services of not only global banks, but also local financial institutions such as cooperative banks, loan funds, credit guarantee funds. Recently, new entities began to mark their presence on the Polish markets, referred to as regional development funds. In many regions they are to play the role of initiators of new solutions in the area of supporting regional entrepreneurship development.

The aim of this article to present the regional financial infrastructure in the process of financing the activity and development of enterprises, as well as to specify the role and position of loan funds, credit guarantee funds and regional development funds, and also to attempt at specifying the challenges faced by those institutions in the future.

\section{The pole and significance of the regional financial infrastritucture}

Micro-, small- and medium-sized enterprises encounter many barriers to their activity, one of the major ones being the limited access to capital and its sources (Pytkowska, Koryński, 2018, p. 1). A significant role in overcoming the obstacles connected with inadequate access to capital is played by the special funds established by the state (Mikołajczyk, 2007, p. 102) as well as regional and local authorities (Flejterski, Pluskota, Szymczak, 2005, pp. 77-80). At the same time, the institutions are perceived as the ones that have an impact on the local development. According to Alińska, the institutions having an impact on the local development also include local governments, local communities represented by households, institutions and organisations responsible for implementation, handling and settlement of the EU programmes and funds, as well as banks and other financial institutions (Alińska, 2008 , p. 87). The latter institutions, being in direct contact with the other market players, play an active part in many business processes taking place in the local environment, in particular by starting cooperation with micro-, small and medium enterprises. Very often the cooperation is relation-based, which gives it a sustainable advantage over the global entities where cooperation is procedure-based, very frequently involving a central decision making organ.

The barriers connected with a possibility of obtaining external funding for both current activities and, perhaps predominantly, for development of enterprises, result from phenomena such as e.g. moral hazard and information asymmetry, and some authors also include transaction costs as another factor (Ashta, 2007, p. 77). The phenomena are often referred to as credit market imperfections, i.e. barriers in the flow of capital to the ones who need it the most (Pluskota, 2013, pp. 37-38).

Poland can boast a relatively well developed system of institutions whose fundamental purpose is financing of business activity. These first and foremost include banks and various kinds of funds, such as loan funds and credit guarantee funds (Bartkowiak, 2009, pp. 109-121). Even though they have their own equity, in periods of economic slowdown they significantly adjust their strategies, tightening their requirements and limiting access to loans, credits and guarantees, and reducing the capital entry. However, it should be noted that the capital resources are limited, and the conditions for obtaining them are relatively restrictive even in the periods of increased economic activity. The latter factor is mainly related to the capital cost amount and the level of required loan security. Difficulties with accessing external sources of financing are experienced mainly by newly founded companies without a credit history or substantial assets, which often have innovative but also risky ideas for business. 
One of the ways to decrease the aforementioned barriers is making use of the funds that are transferred to Poland within the framework of the EU common budget, where the forms of utilising the funds are significantly diversified. With regard to the companies from the SME sector, the funds may take the form of subsidies or be repayable. The latter approach has been the preferable one over the recent years, as it makes the support more effective, enables using diversified financial instruments, creates a financial resource that is reusable via the revolving mechanism, and makes it possible to multiply the value of the support as a result of engaging private funds. Moreover, in the light of sustainable development and the contemporary role of banks being local financial institutions, we should focus on greater involvement of these institutions in implementation of ideas to support entrepreneurs in the area of banking.

The regional market and the financial system creates numerous processes. According to A. Alińska, in the theory of economics there are many concepts and views regarding the impact of the financial system on economic growth (Alińska, 2008, p. 124). Most of them indicate that development of the financial system stimulates economic growth. The mission of regional development should involve any and all local (regional) financial institutions, including those that are not banks, such as loan funds and credit guarantee funds. As research studies have shown, there is a positive correlation between development of the financial system and economic growth. Development of the financial system, also in the regional context, understood as increasing the availability of financial services, makes it possible to effectively fight the financial exclusion and to have a positive effect on the regional development (Beck, Demirguc-Kunt, Levine, p. 1, 29; Beck, Demirguc-Kunt, Martinez Peria, p. 398). In particular, this regards development of a business model which will significantly support the economic growth of the region, and will be favourably perceived by the local community in view of effective fulfilment of their needs and creating a potential for growth (Kulińska-Sadłocha, Szambelańczyk, p. 172).

\section{Activity of loan funds}

The origins of loan funds in Poland date back to the onset of the market economy, when privately-owned enterprises began to encounter problems with financing their business. The first institutions of this type featured a very simple structure and had one goal: to offer loans to enterprises and physical persons starting their business activity, which/who did not meet the criteria set by banks. The history of the institutions dates back to the activity of the microfinance institutions whose main goal was to support people in need of external financing.

A loan fund is understood as an institution other than a bank, whose activity concentrates on providing access to external sources of capital by means of granting loans (Bartkowiak, Flejterski, Pluskota, 2006, pp. 6465). The main idea of loan funds is to offer loans to businesses and physical persons which/who are beginning their business activity and which/who do not meet the banks' requirements regarding documented credit history, acceptable security or higher-than-average risk level (Bartkowiak, 2009, p. 109). They also fulfil the educational function by preparing people to the role of a bank customer, they provide an alternative to bank services and, more and more often, their supplementation. From the onset of the 1990s, loan funds have been supporting the development of Polish enterprises and establishing a nation-wide network of institutions providing external financing to micro-, small and medium enterprises (SME). At the end of 2017, in Poland there were 80 loan funds which in aggregate had at their disposal nearly PLN 2.5 bn of loan capital (in the last year this amount decreased by 13.14\%). In the past, the funds were beneficiaries of the first programmes aimed at supporting entrepreneurship in Poland, as 
a result of which they were able to obtain enduring subsidies financed with EU funds. Currently, loan funds continue to participate in the distribution of EU funding as part of various initiatives, where the funds are repayable.

Many a time, loan funds are the only possibility of financing a business idea. In 2017, they granted 5,096 loans totalling over PLN $500 \mathrm{~m}$. At that time, the average value of one loan amounted to nearly PLN $115 \mathrm{k}$. Although these institutions are active all over the country, in some regions their network is more developed compared to others (Table 1).

Table 1. Distribution and activity of loan funds in the particular regions in 2017

\begin{tabular}{|c|c|c|c|c|c|}
\hline Voivodeship & Number of Funds ${ }^{*}$ & Number of loans & Value of loans & $\begin{array}{c}\text { Share in percent } \\
\text { of total loans }\end{array}$ & $\begin{array}{c}\text { The average loan } \\
\text { value (PLN) }\end{array}$ \\
\hline Dolnośląskie & 3 & 116 & $11,272,400$ & 1.93 & $97,175.86$ \\
\hline Kujawsko-Pomorskie & 6 & 231 & $14,453,417$ & 2.47 & $62,568.90$ \\
\hline Lubelskie & 4 & 550 & $47,447,613$ & 8.11 & $86,268.39$ \\
\hline Lubuskie & 3 & 111 & $14,567,833$ & 2.49 & $131,241.74$ \\
\hline Łódzkie & 7 & 132 & $29,206,649$ & 4.99 & $221,262.49$ \\
\hline Małopolskie & 6 & 446 & $47,246,140$ & 8.07 & $105,933.05$ \\
\hline Mazowieckie & 9 & 350 & $32,663,592$ & 5.58 & $93,324.55$ \\
\hline Opolskie & 2 & 185 & $35,011,357$ & 5.98 & $189,250.58$ \\
\hline Podkarpackie & 5 & 431 & $27,089,282$ & 4.63 & $62,852.16$ \\
\hline Podlaskie & 7 & 175 & $28,054,000$ & 4.79 & $160,308.57$ \\
\hline Pomorskie & 7 & 847 & $72,237,650$ & 12.34 & $85,286.48$ \\
\hline Śląskie & 6 & 154 & $20,185,472$ & 3.45 & $131,074.50$ \\
\hline Świętokrzyskie & 6 & 192 & $33,192,741$ & 5.67 & $172,878.86$ \\
\hline Warmińsko-Mazurskie & 9 & 488 & $68,005,998$ & 11.62 & $139,356.55$ \\
\hline Wielkopolskie & 8 & 347 & $43,448,799$ & 7.42 & $125,212.68$ \\
\hline Zachodniopomorskie & 7 & 341 & $61,237,764$ & 10.46 & $179,582.89$ \\
\hline Total & 95 & 5,096 & $585,320,711$ & 100.00 & $114,858.85$ \\
\hline
\end{tabular}

* The number of funds granting loans in a given province together with branches.

Source: Fundusze pożyczkowe...(2017), p. 19.

Loan funds, which fulfil the role of institutions financing the financial gap, predominantly finance the smallest enterprises, both in terms of quantity and value (Table 2). This coincides with their mission and role in the local communities. The predominant share of microenterprises in the group of loan funds customers has not changed from the beginning of their existence. Firstly, this is a proof they respond to the needs of microenterprises, and secondly it proves the importance of this institution. Otherwise the enterprises which had not been approved by any bank would have been forced to abandon their development plans or limit their operations. Therefore, it may be stated that loan funds have worked out a stable and significant position in local and regional financial markets as well as recognition among entrepreneurs.

The analysis of the purposes of the loans granted by the loan funds provides even further evidence of their role and importance for regional development. In terms of both quantity and value, the predominant share of the loans were used for financing investments that provided a long-standing pro-growth impulse (Table 3 ). 
Table 2. The type of loan funds clients

\begin{tabular}{lcccc}
\hline \multicolumn{1}{c}{ Specification } & $\begin{array}{c}\text { Quantity (number } \\
\text { of enterprices) }\end{array}$ & $\begin{array}{c}\text { Quantity structure } \\
(\%)\end{array}$ & $\begin{array}{c}\text { Value } \\
(\mathrm{PLN})\end{array}$ & $\begin{array}{c}\text { Value structure } \\
(\%)\end{array}$ \\
\hline Micro & 4,539 & 89.07 & $446,041,749.49$ & 76.20 \\
Small & 452 & 8.87 & $107,765,497.75$ & 18.41 \\
Medium & 61 & 1.20 & $24,668,700.00$ & 4.21 \\
Others (eg. public institutions') & 44 & 0.86 & $6,844,764.00$ & 1.17 \\
\hline Total & 5,096 & 100.00 & $585,320,711.24$ & 100.00 \\
\hline
\end{tabular}

*Including social economy institutions, e.g. foundations, associations, cooperatives.

Source: Fundusze pożyczkowe... (2017), p. 28.

Table 3. Loans granted in 2017, broken down by their intended purposes

\begin{tabular}{lcccc}
\hline \multicolumn{1}{c}{ Specification } & $\begin{array}{c}\text { Quantity } \\
\text { (number of loans) }\end{array}$ & $\begin{array}{c}\text { Quantity structure } \\
(\%)\end{array}$ & $\begin{array}{c}\text { Value } \\
(\text { PLN) }\end{array}$ & $\begin{array}{c}\text { Value structure } \\
(\%)\end{array}$ \\
\hline Working capital loan & 1,696 & 13 & $105,284,908.68$ & 18 \\
Investment capital loan & 3,445 & 68 & $401,219,552.33$ & 69 \\
Investment and working capital loan & 955 & 19 & $78,816,250.21$ & 13 \\
\hline Total & 5,096 & 100 & $585,320,711.22$ & 100 \\
\hline
\end{tabular}

* Investments account for over $50 \%$ of the loans value.

Source: Fundusze pożyczkowe...(2017), p. 31.

Loan funds have always participated in implementation of various EU initiatives and programmes, playing the roles of a capital recipient or a distributor of funds to micro-, small and medium enterprises. Recently they have been actively participating in implementation of financial instruments provided by the EU. A good example can be the JEREMIE initiative and fulfilling the role of financial intermediaries in the current perspective for the years 2014-2020. The role they play is fundamental for supporting the development of enterprises in many regions. When commercial banks do not show interest in financing some smaller enterprises burdened with risk, the role of the capital provider is taken over by loan funds. However, the problem that considerably limits the operation scale of those institutions is the capital that is currently required for each tender proceeding organised by funds of funds (FOFs) in particular regions. If the problem remains unsolved, the institutions will have to significantly limit their activities regarding implementation of financial instruments and handing over the funds to final beneficiaries. Tender proceedings require that each participant should have a documented equity contribution necessary for completing the operation. The funds also run active portfolios under the previous perspective (JEREMIE), which require engaging their own capital.

Currently loan funds (similarly as loan guarantee funds) are dependent on EU funding, implementing the regional Operational Programmes. This, however, requires an appropriate amount of equity contribution. Moreover, supporting enterprises by means of repayable financial instruments required prior engagement of own funding being an equity contribution for the purposes of contests held at that time by the Trust Fund Manager. 
Table 4. Activity of loan funds in West Pomerania region in 2015-2017

\begin{tabular}{|c|c|c|c|c|c|c|c|c|c|c|c|c|}
\hline \multirow[t]{2}{*}{ Specification } & \multicolumn{3}{|c|}{$\begin{array}{l}\text { Value of loan capital } \\
\text { at the end (1,000 PLN) }\end{array}$} & \multicolumn{3}{|c|}{$\begin{array}{l}\text { Value of disbursed loans } \\
\qquad(1,000 \mathrm{PLN})\end{array}$} & \multicolumn{3}{|c|}{$\begin{array}{l}\text { Number of disbursed } \\
\text { loans }\end{array}$} & \multicolumn{3}{|c|}{$\begin{array}{c}\text { The average value } \\
\text { disbursed loan } \\
(1,000 \text { PLN) }\end{array}$} \\
\hline & 2015 & 2016 & 2017 & 2015 & 2016 & 2017 & 2015 & 2016 & 2017 & 2015 & 2016 & 2017 \\
\hline $\begin{array}{l}\text { Polska Fundacja } \\
\text { Przedsiębiorczości }\end{array}$ & 308,029 & 284,292 & 275,340 & 112,527 & 72,427 & 70,511 & 890 & 646 & 712 & 126 & 112 & 99 \\
\hline $\begin{array}{l}\text { Szczeciński Fundusz } \\
\text { Pożyczkowy }\end{array}$ & 46,250 & 59,750 & $55,212.5$ & 11,147 & 4,970 & 21,489 & 34 & 8 & 11 & 327 & 621 & 1,900 \\
\hline $\begin{array}{l}\text { Fundacja Centrum Innowacji } \\
\text { i Przedsiębiorczości } \\
\text { w Koszalinie }\end{array}$ & 32,619 & - & $27,175.2$ & 15,091 & - & $3,357.5$ & 92 & - & 24 & 164 & - & 140 \\
\hline $\begin{array}{l}\text { Koszalińska Agencja } \\
\text { Rozwoju Regionalnego }\end{array}$ & 14,392 & 17,076 & 17,872 & 8,098 & 4,785 & $4,364.4$ & 102 & 54 & 35 & 101 & 88 & 125 \\
\hline
\end{tabular}

Source: own elaboration based on reports in 2015-2017 Fundusze pożyczkowe... (2017), pp. 68-79.

There are 7 loan funds operating in the West Pomerania region, and 4 of them have their headquarters there, including the largest institution of this kind in Poland - Polska Fundacja Przedsiębiorczości (Polish Entrepreneurs Foundation, PEF), which supports enterprises also in other regions. The supraregional nature of the Foundation in a way manifests the trends and directions of development of such entities, as the capital capabilities such as intellectual capital make it possible to develop the activity and to diversify the products, which enables making use of products on the European level and playing a significant role on local financial markets. However, in the case of other loan funds operating in West Pomerania, the situation is different. The capital engagement in the implementation of the JEREMIE initiative led to limiting their activity in the years 2016-2017 (Table 4) even though they are currently taking part in tenders under the 2014-2020 perspective. As much as the situation of Szczeciński Fundusz Pożyczkowy (Szczecin Loan Fund) does not appear to be a reason for concern, as it has always granted fewer loans of greater values, the activity of the other two has decreased considerably over the past two years, which in view of the growing competition of other funds (mainly outside the region) might compromise their growth prospects.

Despite the capital constraints, the loan funds are the main if not sole entities that implement loan instruments under the current perspective. The terms of tenders that give priority to qualitative criteria require that financial intermediaries support their end beneficiaries not only fast, but effectively, engaging their own means (Fundusze pożyczkowe..., p. 59). In the near future the loan fund market will have to transform, the current terms of contests and the market conditions will change its structure. Any institutions that have granted only several loans within a year will have to face hard times, which may lead to reducing their number and constraining the possibilities of supporting the SME sector growth. A solution to this problem might be entering into consortium agreements by the funds and their joint participation in tenders. The sector should finally be approached with a comprehensive programme addressed at para-banking loan and loan guarantee institutions that would reinforce their operating capabilities e.g. in the form of special, dedicated products. This could be for example a financial facility for loan funds that take part in tender proceedings under old and new financial instruments increasing their operating capabilities. This kind of a repayable financial instrument will enhance the capital base for some time and will ensure continuity of support for the SME sector. 


\section{The activity of loan guarantee funds}

Loan guarantee funds are institutions that facilitate access to external funding in the form of bank credits or loans to companies which are creditworthy, but do not have the loan security required by the financial institution (Bartkowiak, 2009, p. 109). The institutions constitute an integral part of local financial markets not only in Poland, but also in Europe: for example, AECM (European Association of Guarantee Institutions) integrates such entities coming from 28 member states of the European Union as well as from Bosnia and Herzegovina, Serbia, Russia and Turkey.

Loan guarantee funds take onto themselves part of the risk for the liabilities owed by the enterprise to the bank or another financing institution, making it possible to implement their investment projects and to run their business. According to the AECM terminology, such entities fall into four main categories (www.aecm.eu):

- Mutual Guarantee Societies,

- Private Guarantee Societies,

- Public guarantee institutions,

- Public-Private Partnership initiatives.

Mutual Guarantee Societies are private guarantee institutions with a cooperative or mutual statute, established by enterprises being the capital providers and beneficiaries of their activity. Private Guarantee Societies are founded as initiatives taken by e.g. chambers of commerce or crafts, business federations, banking organisations. The capital is provided by the private shareholders. Public Guarantee Institutions are set up by public authorities, in the form of independent entities that are entirely funded and managed by public shareholders. They are aimed at implementation of the support policy for the SME sector via guarantees or counter-guarantees (re-guarantees) to private Guarantee Societies. The fourth model for running the guarantee activity involves public-private partnerships, where the public shareholder usually holds a minority stake (AECM).

Guarantee institutions play a significant role not only in regional financial markets, but predominantly in relation to enterprises. They facilitate access to external sources of financing without decreasing the financial liability of the borrower, conduct a thorough and wide-ranging analysis of the risk, enrich the analysis with relational aspects and knowledge of the local markets, and ensure support via consulting and supervising in the area of financial management (Mikołajczyk, 2007, p. 107).

As at the end of 2017, there were 41 loan guarantee funds operating in Poland, two fewer than in the previous year (Table 5). The institutions had at their disposal the capital totalling slightly above PLN 1 bn, and active guarantees of under PLN $1.6 \mathrm{bn}$. Year 2017 was another one when the quantity and value of granted guarantees rose by $10 \%$ and $5 \%$, respectively (Gajewski, Kubajek, Szczucki, 2018, pp. 6-9).

Table 5. Regional characteristics of loan guarantee funds in 2017

\begin{tabular}{|c|c|c|c|c|c|c|}
\hline \multirow{2}{*}{ Voivodeship } & \multirow{2}{*}{$\begin{array}{l}\text { Number } \\
\text { of Funds }\end{array}$} & \multirow{2}{*}{$\begin{array}{l}\text { Guarantee capital } \\
\text { (mln PLN) }\end{array}$} & \multirow{2}{*}{$\begin{array}{l}\text { Active guarantees } \\
\quad(\mathrm{mln} \text { PLN) }\end{array}$} & \multicolumn{2}{|c|}{ Granted guarantees in $2017 r$. } & \multirow{2}{*}{$\begin{array}{c}\text { Involvement } \\
\text { of guarantee capital (\%) }\end{array}$} \\
\hline & & & & number & value (mln PLN) & \\
\hline 1 & 2 & 3 & 4 & 5 & 6 & 7 \\
\hline Dolnośląskie & 5 & 39.4 & 65.7 & 450 & 54.1 & 167 \\
\hline Kujawsko-Pomorskie & 4 & 71.7 & 142.2 & 859 & 61.2 & 198 \\
\hline Lubelskie & 3 & 80.5 & 52.9 & 336 & 46.9 & 66 \\
\hline Lubuskie & 1 & 46.9 & 42.3 & 176 & 27.0 & 90 \\
\hline Małopolskie & 3 & 91.9 & 127.7 & 201 & 59.3 & 139 \\
\hline
\end{tabular}




\begin{tabular}{|c|c|c|c|c|c|c|}
\hline 1 & 2 & 3 & 4 & 5 & 6 & 7 \\
\hline Mazowieckie & 2 & 75.7 & 68.6 & 167 & 25.3 & 91 \\
\hline Opolskie & 1 & 16.6 & 13.9 & 157 & 12.9 & 84 \\
\hline Podkarpackie & 2 & 9.9 & 15.2 & 58 & 2.6 & 153 \\
\hline Podlaskie & 2 & 78.6 & 43.2 & 207 & 17.6 & 55 \\
\hline Pomorskie & 2 & 49.3 & 107.7 & 427 & 67.7 & 219 \\
\hline Śląskie & 2 & 52.5 & 61.9 & 964 & 82.1 & 118 \\
\hline Świętokrzyskie & 2 & 39.0 & 24.6 & 77 & 13.8 & 63 \\
\hline Warmińsko-Mazurskie & 4 & 77.9 & 77.9 & 465 & 44.6 & 100 \\
\hline Wielkopolskie & 4 & 102.0 & 425.5 & 2,494 & 311.6 & 417 \\
\hline Zachodniopomorskie & 4 & 174.2 & 322.0 & 1,148 & 173.1 & 185 \\
\hline Total & 41 & $1,006.1$ & $1,591.4$ & 8,186 & 999.8 & 158 \\
\hline
\end{tabular}

Source: Gajewski, Kubajek, Szczucki (2018), pp. 17-18.

As per their definition, loan guarantee funds constitute a supplementation of banking lending products, which means they support entrepreneurs in their relations with banks with regard to securing the transactions. In the past, guarantees dominated predominantly, and their value was growing. However, the changing realities in the loan guarantee and surety market distorted the rising trend. Over the past two years, there has been a noticeable decrease in the share of both quantity and value of loan guarantees in relation to banks (Table 6). This is a result of the competitive activities of the central programmes operated by state-run Bank Gospodarstwa Krajowego (BGK), such as De Minimis guarantee line, or the Intelligent Development Operational Programme (PO IR) and the programmes distributed on the European level, e.g. COSME$^{1}$ (Programme for the Competitiveness of Enterprises and small and medium-sized enterprises), Horizon 2020 or EaSl ${ }^{2}$ (EU Programme for Employment and Social Innovation).

Table 6. Loan guarantees granted, broken down by financing institution, in 2015-2017

\begin{tabular}{|c|c|c|c|c|c|c|c|c|c|}
\hline \multirow[t]{2}{*}{ Specification } & \multicolumn{3}{|c|}{ Quantity (number of guarantees) } & \multicolumn{3}{|c|}{$\begin{array}{l}\text { Value of guarantees } \\
\qquad(\mathrm{m} \ln \mathrm{PLN})\end{array}$} & \multicolumn{3}{|c|}{$\begin{array}{l}\text { Average value of guarantee } \\
\qquad(\mathrm{m} \ln \mathrm{PLN})\end{array}$} \\
\hline & 2015 & 2016 & 2017 & 2015 & 2016 & 2017 & 2015 & 2016 & 2017 \\
\hline Total & 6,336 & 7,453 & 8,186 & 923.8 & 949.5 & 999.8 & 145.8 & 127.4 & 122.1 \\
\hline \multicolumn{10}{|c|}{ including for } \\
\hline Banks & 3,939 & 3,548 & 3,033 & 761.2 & 712.3 & 653 & 193.2 & 200.8 & 215.2 \\
\hline Loan Funds & 766 & 634 & 486 & 55.2 & 46.6 & 31 & 72.1 & 73.5 & 64.4 \\
\hline Other entities & 1,631 & 3,271 & 4,667 & 107.3 & 190.6 & 316 & 65.8 & 58.3 & 67.7 \\
\hline
\end{tabular}

Source: Gajewski, Kubajek, Szczucki (2018), p. 18.

Forced to search for new ways of running their activity, the loan guarantee funds began to engage actively in guaranteeing bid bonds which in terms of quantity now account for $50 \%$ of the funds' activities. Lease transaction guarantees and performance bonds take up considerably smaller shares, however, they are the evidence of the activity diversification and searching for new solutions. The distinct predominance of bid bonds in the loan guarantee

\footnotetext{
1 Programme for the Competitiveness of Enterprises and SMEs 2014-2020.

2 Programme for Employment and Social Innovation (EaSI) 2014-2020.
} 
funds' portfolios on the one hand is a proof of their flexibility, but on the other hand raises some doubts with regard to the original assumptions of their existence. This is a sign of some kind of erosion of the role played by the funds in the area of securing debt transactions to complement lending products. As a result of the competition from the governmental programmes and the weak interest shown by commercial banks in further cooperation with many regional intermediaries, they have to look for new ways to run their business, in particular via smaller, local and regional funds. One of the options is diversification of the activity, mainly with regard to the product range, and close cooperation with loan funds and cooperative banks. Being local by nature, cooperative banks fully understand the specificity of guarantee entities and they should cooperate within groups, consortia, or on their own.

Table 7. Activity of loan guarantee funds in West Pomerania region in 2015-2017

\begin{tabular}{|c|c|c|c|c|c|c|c|c|c|}
\hline \multirow{3}{*}{ Specification } & \multicolumn{3}{|c|}{ Capital (1,000 PLN) } & \multicolumn{6}{|c|}{ Guarantees granted } \\
\hline & \multirow[b]{2}{*}{2015} & \multirow[b]{2}{*}{2016} & \multirow[b]{2}{*}{2017} & \multicolumn{2}{|c|}{2015} & \multicolumn{2}{|c|}{2016} & \multicolumn{2}{|c|}{2017} \\
\hline & & & & number & $\begin{array}{c}\text { value } \\
(1,000 \mathrm{PLN})\end{array}$ & number & $\begin{array}{c}\text { value } \\
(1,000 \mathrm{PLN})\end{array}$ & number & $\begin{array}{c}\text { value } \\
(1,000 . P L N)\end{array}$ \\
\hline \multicolumn{10}{|c|}{ Stargardzka Agencja Rozwoju } \\
\hline Regionalnego & 4,003 & 4,003 & 3,000 & 67 & 4,189 & 43 & 2,717 & 78 & 2,991 \\
\hline \multicolumn{10}{|c|}{ Agencja Rozwoju Metropolii } \\
\hline Szczecińskiej & 72,537 & 53,512 & 53,414 & 42 & 18,297 & 9 & 685 & 20 & 2,757 \\
\hline \multicolumn{10}{|c|}{ POLFUND Fundusz Poręczeń } \\
\hline Kredytowych & 84,728 & 85,477 & 86,356 & 792 & 129,702 & 770 & 145,694 & 661 & 127,436 \\
\hline Fundusz Pomerania & 29,795 & 29,656 & 31,454 & 326 & 40,027 & 448 & 32,985 & 389 & 39,956 \\
\hline
\end{tabular}

Source: Gajewski, Kubajek, Szczucki (2018), pp. 33-34.

Loan guarantee institutions show considerable activity in the West Pomerania region (Table 7). The biggest one in the region is POLFUND, a nationwide fund that is also actively involved in EU programmes. The other three entities, which are considerably smaller and whose activity is narrowed down to the territory of the region, have been affected by the popularity of the governmental programmes among commercial banks, and they have to look for new solutions.

\section{Regional development funds}

Another element of the regional financial markets and one of the elements of the Strategy for Sustainable Development are regional development funds (RDF) which pursuant to that document are to be established in each region. The purpose of regional development funds is to finance regional development activities using the financial resources repaid by the end beneficiaries of the previous perspective, which are to be reused in the form of repayable instruments (Strategia na rzecz..., 2017, pp. 207-208). Ten local self-governments have chosen two ways for running the activity. The first of them is establishing totally new institutions (7 regions), and the other stipulates running the activity within the framework of the existing regional development agencies ( 3 regions). Regional development funds, where the local self-governments are the sole or major shareholders, have been provided with capital coming from e.g. JEREEMIE and JESSICA initiatives in order to play the role of a stimulator and creator of repayable assistance in the regions. The entities should also skilfully distribute the funds so as not to compete with the financial instruments coming from the current perspective. Moreover, they may play a major role in constructing instruments that support not only enterprises, but also regional and local financial intermediaries, 
in particular in the light of the already mentioned capital shortage affecting some of them. In the future, their role and significance may rise, as they may also become integrators of lending and guarantee activities in the regions. In some regions it is planned to use them as the basis for establishing regional banks of development, following the example of their German counterparts.

Establishing the regional development funds will change the structure of regional financial markets. On the one hand, they may become institutions that manage the regional funds deriving from the Regional Operational Programmes, and on the other hand play the role of intermediaries that promote the regional development and intervene, if necessary, when there is a need to mitigate irregularities of the financial market.

\section{Conclusions}

Summing up, loan funds provide numerous benefits not only to enterprises, but also local communities, where their activity is promoted thanks to loans. Currently the funds' operation faces challenges in the form of shortage of capitals that are necessary for participating in subsequent tender proceedings. The problem may be solved in many complementary ways. The first of them is sustainable capital injections by the owners of the entities. The second way is providing support on the central level, in the form of programmes that enable increasing the capital value, which could be the task of e.g. the Polish Development Fund (PFR). The optimum solution would be sustainable capital injections into the funds, however, preferential loans would also in way help mitigate the problem for some time. The third solution covers the special regional financial products dedicated to intermediaries for the purposes of a capital injection. The financial resources may be derived from the revolved financial instruments of the JEREMIE initiative. The capitals used in the 2007-2013 perspective of the JEREMIE initiative have been repaid and now they are at the disposal of the voivodeship governors, and they may be reused to support enterprises. Such an innovative approach is already practised in some regions, in particular where regional development funds have been established. Regional development funds are currently managing the resources that were once used under the JEREMIE and JESSICA initiatives, and now the means will serve to help enterprises yet another time. Some of the financial resources may be used to create repayable financial instruments intended for preferential support of loan funds.

Loan guarantee funds also face immense challenges, as they are losing the unequal fight with the centrally run programmes. Looking for their niche, the funds are forced to find new forms of activity, both in terms of institutional cooperation and product diversification. In order to survive, the funds will be looking for new products or create new solutions for supporting SMEs.

Due to the capitals coming from the Regional Operational Programmes, European financial institutions and centrally run organisations, the regional structure of financial market is subject to change. The transformations may also affect both loan and loan guarantee funds, and also have an influence on increasing the importance of regional development funds that may become the local managers and stimulators of regional development, in its broad sense and in a long-time perspective. 


\section{References}

Alińska, A. (2008). Instytucje mikrofinansowe w lokalnym rozwoju społeczno-gospodarczym. Warszawa: Wydawnictwo Szkoły Głównej Handlowej w Warszawie.

Ashta, A. (2007). An Introduction to Microcredit: Why money is flowing from the rich to the poor. Working Papers in Cahiers du CEREN, 21, 77-87. Retrieved from: https://www.microfinancegateway.org/sites/default/files/mfg-en-paper-an-introduction-tomicrocredit-why-money-is-flowing-from-the-rich-to-the-poor-2007_0.pdf.

Bartkowiak, B. (2009). Fundusze pożyczkowe i poręczeniowe w finansowaniu małych i średnich przedsiębiorstw w Polsce. Warszawa: CeDeWu.pl.

Bartkowiak, B., Flejterski, S., Pluskota, P. (2006). Fundusze i usługi pożyczkowe dla mikro, małych i średnich przedsiębiorstw. Warszawa: Difin.

Beck, T., Demirguc-Kunt, A., Levine, R. (2004). Finance, Inequality and Poverty: Cross Country Evidence. World Bank Policy Research Working Paper 3338, June 2004. Retrieved from: http://documents.worldbank.org/curated/en/824991468778185410/pdf/ wps3338.pdf.

Beck, T., Demirguc-Kunt, A., Martinez Peria, M.S. (2008), Banking Services for Everyone? Barriers to Bank Access and Use around the World. The World Bank Economic Review, 22 (3), 397-430.

Flejterski, S., Pluskota, P., Szymczak, I. (2005). Instytucje i usługi poręczeniowe na rynku finansowym. Warszawa: Difin.

Fundusze pożyczkowe w Polsce. Raport 2017 (2018). Warszawa: Polski Związek Funduszy Pożyczkowych.

Gajewski, M., Kubajek, R., Szczucki, J. (2018). Raport o stanie funduszy poręczeniowych w Polsce - stan na dzień 31.12 .2017 r. Warszawa: Krajowe Stowarzyszenie Funduszy Poręczeniowych.

Kulińska-Sadłocha, E., Szambelańczyk, J. (2014). Rola i funkcje lokalnych instytucji kredytowych w Polsce w realizacji koncepcji zrównoważonego rozwoju. In: S. Flejterski, A. Gospodarowicz (eds.), Banki w społecznej gospodarce rynkowej w świetle doświadczeń z kryzysu i stanu rozwoju rynku finansowego (pp. 154-172). Szczecin: Wydawnictwo Zapol.

Mikołajczyk, B. (2007). Infrastruktura finansowa MSP w krajach Unii Europejskiej. Warszawa: Difin.

Strategia na rzecz Odpowiedzialnego Rozwoju do roku 2020 (z perspektywą do 2030 r.) (2017). Warszawa: Ministerstwo Inwestycji i Rozwoju.

Pluskota, P. (2013). Mikrofinanse w ograniczaniu niedoskonałości rynków kredytowych. Warszawa: Cedewu.pl.

Pytkowska, J., Koryński, P. (2018). Between the needs and availability: the external financing gap indicator. Focus on Enterprise, Microfinance Centre. Retrieved from: https://aecm.eu/members/what-are-guarantee-institutions.

Cite this article aS: Pluskota, P. (2018). Challenges faced by the regional financial institutions engaged in enterprise financing. European Journal of Service Management, 4 (28/2), 339-349. DOI: 10.18276/ejsm.2018.28/2-40. 